\title{
Analisis Perilaku Konsumen Usia Muda di Kota Bogor dalam Mengonsumsi Susu dan Produk Olahannya di Masa Pandemi Covid 19
}

\author{
Analysis of Adult Consumers Behavior in Bogor City in Consuming Milk and Its Processed Products \\ During the Covid-19 Pandemic
}

N. H. Rachmani, A. Apriantini*, \& L. Cyrilla E. N. S. D

Departemen Ilmu Produksi dan Teknologi Peternakan, Fakultas Peternakan, Institut Pertanian Bogor

J1. Agatis, Kampus IPB Darmaga, Bogor, 16680, Indonesia

*Corresponding author: astariapriantini@yahoo.com

(Received 19-08-2021; Revised 30-09-2021; Accepted 14-10-2021)

\begin{abstract}
During the COVID-19 pandemic, people are started to consume foods that are highly nutritious to increased their immunity, one of them is by consuming milk and its processed products like kefir, yogurt. Milk is one of the foods favored by the community because it is rich in health benefits. The demand for this product is also increased every year. Consumer behavior was always changing along with consumer needs that follow the conditions and developments of the times. Consumers will choose products with good quality and ful fill what their needs, as well as dairy products. This study aims to analyze consumer decisions in consuming milk and its processed products in the Bogor city area during the covid 19 pandemic. The research was carried out with the stages of determining respondents, identify factors that influence consumer behavior, collecting and analyzing data. Respondents are people who live in Bogor City with an age range of 20 to 30 years purposively as many as 108 respondents. Data processing and analysis was carried out using the Spearman rank correlation test to determine the relationship between knowledge and situational variables on the decision to consume milk and its processed products. The results showed that the level of knowledge and situational had a significant and direct relationship with consumer decisions $(\mathrm{P}<\mathbf{0 . 0 1})$. This shows that the higher level of consumer knowledge of products with supportive conditions, the consumer's decision to consume milk and its processed products is also getting stronger.
\end{abstract}

Keywords: consumer behaviour, dairy products, milk, young age

\section{ABSTRAK}

Dimasa pandemi COVID-19 saat ini masyarakat mulai mengonsumsi pangan yang berkhasiat tinggi untuk meningkatkan imunitas tubuh, salah satunya dengan mengonsumsi susu dan produk olahannya seperti kefir, yogurt. Susu menjadi salah satu pangan yang digemari masyarakat karena kaya akan khasiatnya terhadap kesehatan. Angka permintaan produk ini juga selalu meningkat tiap tahunnya. Perilaku konsumen selalu berubah seiring kebutuhan konsumen yang mengikuti kondisi dan perkembangan zaman. Konsumen akan memilih produk dengan kualitas yang baik serta dapat memenuhi kebutuhannya, begitu pula pada produk susu. Penelitian ini bertujuan menganalisis keputusan konsumen dalam mengonsumsi susu serta produk olahannya di wilayah kota Bogor di masa pandemik COVID-19. Penelitian dilakukan dengan tahapan penentuan responden, Identifikasi faktor yang mempengaruhi perilaku konsumen, pengumpulan dan analisis data. Responden adalah masyarakat yang berdomisili di Kota Bogor dengan rentang usia 20 hingga 30 tahun secara purposive sampling berjumlah 108 orang. Pengolahan dan analisis data dilakukan menggunakan uji korelasi rank Spearman untuk mengetahui hubungan variabel pengetahuan dan situasional terhadap keputusan mengonsumsi susu dan produk olahannya. Hasil menunjukkan tingkat pengetahuan dan situasional memiliki hubungan yang signifikan dan searah dengan keputusan konsumen $(\mathbf{P}<0.01)$. Hal ini menunjukkan bahwa semakin tinggi tingkat pengetahuan konsumen terhadap produk dengan kondisi situasi yang ikut mendukung maka keputusan konsumen dalam mengonsumsi susu dan produk olahannya juga semakin kuat.

Kata kunci: perilaku konsumen, produk olahan susu, usia muda 


\section{PENDAHULUAN}

COVID-19 merupakan virus yang dapat menimbulkan penyakit terhadap manusia dan hewan. Corona virus yang terbaru adalah yang menyebabkan COVID-19 dimana penyakit ini mampu menularkan antar sesama yang baru ditemukan saat ini (Sukur et al. 2020). Hal ini dibutuhkan berbagai cara pencegahan penularan covid 19, salah satunya dengan peningkatan imunitas tubuh dengan cara mengonsumsi pangan yang berkhasiat tinggi untuk tubuh. Susu dan produk olahannya seperti yogurt, kefir menjadi salah satu pilihan pangan yang dikonsumsi oleh masyarakat selain karena harganya yang terjangkau, produk ini pun telah tersebar di berbagai daerah di Indonesia sehingga produk ini mudah didapatkan oleh berbagai kalangan masyarakat.

Perilaku konsumen merupakan tindakan konsumen dalam memilih, membeli menggunakan barang untuk memenuhi kebutuhan maupun kepuasan mereka (Kotler 2009). Konsumen memiliki pilihan dalam mengonsumsi produk yang dinilai memiliki keuntungan dari segi kualitas produk maupun manfaat akan kebutuhan produk tersebut. Produk pangan yang memiliki manfaat akan kesehatan seperti susu dan produk olahannya akhir-akhir ini menjadi produk yang banyak digemari oleh masyarakat. Kondisi ini memungkinkan terjadinya peningkatan angka konsumsi susu selama pandemik sebagai salah satu pangan yang dapat meningkatkan aktivitas imun tubuh.

Susu merupakan cairan dari ambing hewan ternak seperti sapi yang bersih dan sehat didapatkan melalui proses pemerahan yang tepat, serta memiliki kandungan alami tanpa penambahan atau pengurangan perlakuan apapun (BSN 2011). Semakin berkembangnya zaman, susu terus mengalami diferensiasi produk tak hanya diminum secara langsung sebagai susu murni namun saat ini mulai berkembang berbagai produk olahan susu seperti susu pasteurisasi. susu UHT, yogurt, kefir dan lain sebagainya. Pengembangan pada produk olahan susu dilakukan agar mampu menjangkau seluruh masyarakat Indonesia yang memiliki kebutuhan berbeda- beda. Persaingan industri susu dalam memberi informasi terkait produk susu dapat mempengaruhi keputusan konsumsi dalam mengonsumsi produk. Konsumen dalam mengonsumsi produk memiliki berbagai pertimbangan salah satunya yaitu dari segi atribut produk.

Kelompok dewasa lajang (19-24 tahun) memiliki perhatian akan kesehatan yang tinggi sehingga pangan dengan gizi tinggi lebih diminati pada kelompok ini untuk memenuhi kebutuhan (Hiam dan Schewe 1994). Protein pada susu memiliki kandungan berupa asam amino esensial serta nilai biologis yang tinggi (90\%) dibandingkan dengan sumber protein pangan lainnya. Nilai biologis menunjukkan nilai persentase protein yang mampu diserap oleh tubuh. Selain itu, susu juga mengandung karakteristik bioaktif yang berfungsi dalam memperbaiki fungsi fisiologis pada tubuh (Taufik 2021). Komponen bioaktif memiliki fungsi yaitu sebagai antikanker, antipatogen, antiinflamasi, aktivitas antioksidan, meningkatkan imunitas tubuh dan lain-lain. Konsumsi susu mampu meningkatkan imunitas tubuh terhadap serangan virus dan patogen. Sehingga susu menjadi salah satu solusi untuk membantu mempertahankan kondisi tubuh agar terhindar dari infeksi COVID-19.

Perilaku konsumen perlu dipelajari untuk mengetahui kebutuhan konsumen dalam memperoleh suatu produk karena permintaan konsumen yang terus berubah setiap waktunya (Dharmesta dan Irawan 1999). Memperlajari terkait perilaku konsumen menjadi hal yang perlu dilakukan terutama bagi produsen agar mampu memenuhi kebutuhan dan keinginan konsumen sehingga semua kalangan umur tertarik untuk membeli dan mengonsumsi susu yang dapat meningkatkan angka konsumsi susu. Konsumen memiliki berbagai pertimbangan dalam mengonsumsi suatu produk, salah satunya yaitu terkait atribut produk. Informasi atribut produk yang dimiliki oleh konsumen akan mempengaruhi konsumen dalam mengambil keputusan. Tujuan dari penelitian ini adalah menganalisis keputusan konsumen dalam mengonsumsi susu dan produk olahannya di wilayah kota Bogor.

\section{MATERI DAN METODE}

\section{Materi}

Penelitian ini dilakukan kepada konsumen yang berada di lokasi kota Bogor yang yang mengonsumsi susu dan produk olahannya dengan rentang usia mulai dari 20 hingga 30 tahun. Lokasi dipilih secara purposive sampling dengan pertimbangan bahwa kota tersebut berada di dekat pusat ibu kota Jakarta sehingga diharapkan jumlah contoh yang diambil akan beragam dan bisa mewakili individu di Indonesia yang aktif dan memiliki kebiasaan mengonsumsi susu dan produk olahannya seperti yogurt, kefir. Materi yang digunakan di penelitian ini adalah data kuisioner responden. Kuesioner disebar kepada responden secara daring melalui form daring dimana terdapat kriteria khusus untuk responden yang dapat mengisi kuesioner. Penelitian dibagi menjadi empat tahap yaitu (1) penentuan responden, (2) identifikasi faktor yang mempengaruhi perilaku konsumen, (3) pengumpulan dan (4) analisis data.

\section{Metode}

\section{Penentuan Responden}

Responden penelitian ini adalah kalangan usia muda mulai umur 20 hingga 30 tahun yang pernah mengonsumsi madu dan susu serta tinggal di kota Bogor yang dipilih dengan teknik purposive sampling. Batas toleransi sebesar $10 \%$ diterapkan dalam penentuan jumlah responden, dimana penentuan ini dilakukan dengan metode slovin. Menurut data BPS (2016) didapatkan jumlah masyarakat kota Bogor berjumlah 178.783 orang dengan rentang usia 20-30 tahun sehingga berdasarkan hasil perhitungan dengan metode Slovin, data responden yang akan diambil berjumlah 108 orang.

\section{Identifikasi Faktor yang Mempengaruhi Perilaku Konsumen}

Keputusan konsumen dalam mengonsumsi produk susu dan olahannya perlu diketahui apa saja faktor yang dapat mempengaruhinya. Penelitian ini diidentifikasi dari 
faktor internal yaitu berupa tingkat pengetahuan konsumen dan faktor eksternal berupa kondisi situasional konsumen.

\section{Pengumpulan dan Analisis Data}

\section{a) Uji Validitas}

Uji validitas dilakukan terhadap 30 responden sebagai salah satu syarat pengujian. Pengukuran dilakukan dengan aplikasi software SPSS statistics 25 untuk mengetahui setiap pertanyaan apakah valid atau tidak dengan syarat: a. Jika $r$ hitung $\geq r$ tabel dengan signifikansi $95 \%$, maka instrumen tersebut dinyatakan valid. b. Jika $r$ hitung $\leq \mathrm{r}$ tabel dengan signifikansi 95\%, maka instrumen tersebut dinyatakan tidak valid (Sugiyono 2005). Uji validitas dilakukan dengan membandingkan nilai $r$ hitung pada setiap butir pertanyaan dengan $r$ tabel untuk degree of freedom $(\mathrm{df})=\mathrm{n}-\mathrm{k}$, dalam hal ini $n$ adalah jumlah sampel dan $\mathrm{k}$ adalah jumlah item. Jika $\mathrm{r}$ hitung $>\mathrm{r}$ tabel, maka pertanyaan tersebut dikatakan valid (Ghozali 2011). Berdasarkan hasil olahan data, sebanyak 39 responden menunjukkan data telah valid 100\% sehingga tidak ada data yang kosong. Pengujian realibilitas dan validitas dilakukan untuk mengetahui aspek apa saja yang mempengaruhi konsumen dalam mengambil keputusan mengonsumsi produk susu dan produk olahannya.

b) Uji Reliabilitas

Uji reliabilitas digunakan untuk mengetahui konsistensi suatu alat ukur. Suatu alat ukur dapat disebut memiliki realibilitas jika digunakan berulang-ulang oleh peneliti yang menunjukkan hasil yang sama (Rakhmat 2001). Melalui kriteria uji reliabilitas menggunakan rumus Alpha adalah $r$ hitung $>r$ tabel dengan taraf signifikansi 0.05 maka alat ukur tersebut dinyatakan reliabel, dan sebaliknya apabila $r$ hitung. Hasil olahan data pada uji reliable didapatkan hasil nilai cronbach 0.675 (Tabel 1) hal ini menunjukkan pertanyaan pada kuesioner reliable, sehingga penelitian dapat dilanjutkan. Uji yang digunakan pada penelitian ini adalah uji Deskriptif dan uji Inferensi. Tujuan dari penelitian deskriptif adalah untuk membuat deskripsi secara objektif mengklasifikasi, menganalisis, dan menginterpretasikan data yang diteliti untuk mempermudah

Tabel 1. Pengaruh variabel pengetahuan dan situasional terhadap perilaku konsumen

\begin{tabular}{|c|c|c|c|c|c|}
\hline No & Variabel & $\begin{array}{c}\text { Item } \\
\text { pertanyaan }\end{array}$ & $\begin{array}{c}\mathrm{R} \\
\text { hitung }\end{array}$ & $\begin{array}{c}\mathrm{R} \\
\text { tabel }\end{array}$ & Ket. \\
\hline \multirow[t]{3}{*}{1} & Variabel & $\mathrm{x} 1.1$ & 0.486 & 0.316 & Valid \\
\hline & & $\mathrm{x} 1.2$ & 0.354 & 0.316 & Valid \\
\hline & & $\mathrm{x} 1.3$ & 0.572 & 0.316 & Valid \\
\hline \multirow[t]{3}{*}{2} & $\begin{array}{c}\text { Variabel } \\
\text { situasional }\end{array}$ & $\mathrm{x} 2.1$ & -0.221 & 0.316 & $\begin{array}{l}\text { Tidak } \\
\text { valid }\end{array}$ \\
\hline & & $\mathrm{x} 2.2$ & 0.031 & 0.316 & $\begin{array}{l}\text { Tidak } \\
\text { valid }\end{array}$ \\
\hline & & $\mathrm{x} 2.3$ & 0.031 & 0.316 & $\begin{array}{l}\text { Tidak } \\
\text { valid }\end{array}$ \\
\hline
\end{tabular}

Sumber: Data primer yang diolah (2021) memahami variabel-variabel yang digunakan dalam penelitian. Penelitian ini menggunakan skala Likert sebagai alat pengukur tiap-tiap indikator variabel. Rentang nilai skala tersebut adalah 1 - 4 (Sugiyono 2013).

Skala Likert merupakan skala yang menunjukkan ulasan konsumen terhadap karakteristik produk (sangat setuju, setuju, tidak setuju, dan sangat tidak setuju). Informasi yang didapatkan berupa skala ordinal sehingga untuk hasil dapat dibuat ranking tanpa diketahui berapa besar selisih antar ulasan yang didapat (Durianto et al. 2004). Tahapan Skala Likert yaitu peneliti menyatukan karakteristik produk yang signifikan dengan permasalahan yang sedang diteliti. Kemudian karakteristik diminta ulasan dari responden yang cukup mewakili dari populasi yang ingin diteliti.

\section{c) Uji Korelasi Rank Spearman}

Uji korelasional Rank Spearman digunakan untuk mengukur hubungan antar variabel yang memiliki skala ordinal. Variabel yang diukur hubungannya pada penelitian ini adalah persepsi dengan karakteristik konsumen. Berikut rumus uji korelasi Rank Spearman (Silalahi 2012):

$$
r s=1-\frac{6 \Sigma d^{2}}{n\left(n^{2}-1\right)}
$$

Keterangan: rs: Nilai koefisien korelasi Spearman; d: Selisih antara kedua perangkat peubah; dan n: Banyaknya peubah

\section{HASIL DAN PEMBAHASAN}

\section{Karakteristik Responden}

Jumlah responden yang mengonsumsi susu dan produk olahannya terdapat pada Tabel 2. Hasil kuesioner didapatkan berdasarkan jenis kelamin jumlah responden wanita lebih banyak dibandingkan dengan pria. Konsumen perempuan sebanyak $69.5 \%$ sedangkan konsumen pria sebanyak 30.5\%. Hal ini menunjukkan pengambilan keputusan terhadap konsumsi susu dan produk olahannya didominasi oleh wanita. Hal ini karena wanita dianggap lebih memiliki pengetahuan dan kesadaran akan pentingnya mengonsumsi makanan sehat dan bergizi tinggi, serta lebih menunjukkan perhatian yang lebih besar terkait keamanan makanan dan kesehatan tubuh (Hartono 2006).

Tingkat pendidikan terakhir pada responden paling banyak yaitu jenjang SMA sebanyak 51.8\% kemudian dilanjut setingkat sarjana sebanyak $37.09 \%$ dan setingkat diploma $11.11 \%$. Tingginya pendidikan yang telah ditempuh menunjukkan perilaku yang semakin cerdas dan bijaksana dalam mengonsumsi suatu produk barang. Pengambilan keputusan konsumen dipengaruhi perilaku konsumen yang kritis, cerdas dan teliti dalam mencari informasi produk maupun jasa yang akan dibeli. Pendidikan mampu mempengaruhi konsumen dalam memiliki produk yang sesuai dengan keinginan karena tingkat pendidikan seseorang akan mempengaruhi nilai-nilai yang dianutnya, cara berfikir, cara pandang, bahkan pengetahuan dan persepsi terhadap suatu produk yang dikonsumsi (Fazrina 2013).

Pekerjaan responden pada Tabel 2 terdapat paling banyak yaitu merupakan pelajar/mahasiswa sebanyak $74 \%$, pegawai swasta/wiraswasta sebanyak $8.3 \%$, ibu rumah tangga sebanyak $5.6 \%$ dan terakhir sebanyak $3.7 \%$ 
Tabel 2. Karakteristik responden

\begin{tabular}{|c|c|c|}
\hline Karakteristik & $\begin{array}{l}\text { Frekuensi } \\
\text { (n) }\end{array}$ & $\begin{array}{c}\text { Persentase } \\
(\%)\end{array}$ \\
\hline \multicolumn{3}{|l|}{ Jenis kelamin } \\
\hline Pria & 33 & 30.5 \\
\hline Wanita & 75 & 69.5 \\
\hline Total & 108 & 100 \\
\hline \multicolumn{3}{|l|}{ Pendidikan Terakhir } \\
\hline SMA & 56 & 51.8 \\
\hline Sarjana & 40 & 37.09 \\
\hline Diploma & 12 & 11.11 \\
\hline Total & 108 & 100 \\
\hline \multicolumn{3}{|l|}{ Jumlah Pendapatan } \\
\hline Rp0-Rp500.000,00 & 50 & 46.2 \\
\hline$>$ Rp500.000,00- Rp1.000.000,00 & 16 & 14.8 \\
\hline$>$ Rp1.000.000,00- Rp1.500.000,00 & 11 & 10.3 \\
\hline$>$ Rp1.500.000,00- Rp2.000.000,00 & 4 & 3.7 \\
\hline$>\operatorname{Rp} 2.000 .000,00$ & 27 & 25 \\
\hline Total & 108 & 100 \\
\hline \multicolumn{3}{|l|}{ Jenis Pekerjaan } \\
\hline Pelajar/mahasiswa & 80 & 74.1 \\
\hline Karyawan & 4 & 3.7 \\
\hline Pegawai & 9 & 8.3 \\
\hline swasta/wiraswasta & 6 & 5.6 \\
\hline Ibu rumah tangga & 9 & 8.3 \\
\hline Lainnya & 108 & 100 \\
\hline Total & & \\
\hline
\end{tabular}

Sumber: Data primer yang diolah (2021)

memiliki pekerjaan sebagai karyawan. Pekerjaan yang dimiliki responden beriringan dengan jumlah pendapatan. Jumlah pendapatan per bulan pada responden penelitian bervariasi dari nominal kurang dari Rp500.000,00 hingga lebih dari Rp2.000.000,00. Data menunjukkan pendapatan responden dengan rentang $\mathrm{Rp} 1.500 .000,00-\mathrm{Rp} 2.000 .000,00$ memiliki persentase terendah sebanyak $3.7 \%$ sedangkan persentase tertinggi sebanyak $46.2 \%$ responden memiliki pendapatan kurang dari Rp500.000,00. Responden pada penelitian ini mayoritas merupakan seorang pelajar atau mahasiswa sehingga angka pendapatan masih tergolong rendah. Pendapatan menjadi salah satu faktor tingkat konsumsi suatu produk oleh konsumen. Hal ini karena Menurut Sukirno (2005) terdapat hubungan yang searah antara pendapatan dan konsumsi. Pendapatan yang tinggi dapat meningkatkan minat mengonsumsi suatu produk. Sehingga semakin tinggi pendapatan maka semakin tinggi juga pembelian suatu produk.

\section{Tingkat Konsumsi Susu dan Produk Olahannya}

Tingkat konsumsi susu dan pada responden diketahui pada Gambar 1. Hasil kuesioner menunjukkan responden memiliki kebiasaan mengonsumsi susu dan produk olahannya seperti es krim, kefir, yogurt terdapat sebanyak $96 \%$ orang memiliki kebiasaan mengonsumsi dan 4\% tidak memiliki kebiasaan mengonsumsi (Gambar 1). Hal ini menunjukkan tingginya angka konsumsi susu dan produk olahannya dibandingkan dengan produk pada masyarakat wilayah kota Bogor usia muda. Produk yang banyak dikonsumsi merupakan produk susu hal ini disebabkan mudahnya produk susu yang ditemui di berbagai tempat dengan harga yang mudah dijangkau oleh konsumen dengan usia dewasa awal sehingga menjadi faktor lebih tingginya angka konsumsi susu terutama oleh mahasiswa yang rata-rata merupakan konsumen dewasa awal. Pengetahuan konsumen terkait produk dan susu ikut mempengaruhi tingginya angka konsumsi, hal ini sesuai dengan Tabel 3 yang menunjukkan tingginya pengetahuan konsumen terhadap produk susu.

\section{Sikap Konsumen Terhadap Susu dan Produk Olahannya}

Pada variabel pernyataan sikap responden diminta untuk memberikan pernyataan sikap mulai dari sangat setuju, setuju, tidak setuju dan sangat tidak setuju. Terdapat 2 variabel X yaitu pengetahuan (X1) dan situasional (X2) yang mempengaruhi terhadap variabel $\mathrm{Y}$ yaitu keputusan mengonsumsi. Diketahui sebanyak 56.29\% responden setuju bahwa pengetahuan dapat mempengaruhi keputusan mengonsumsi, $36.62 \%$ sangat setuju, $3.51 \%$ tidak setuju dan $0.56 \%$ sangat tidak setuju. Kemudian dalam variabel situasional $49.69 \%$ setuju kondisi situasional responden

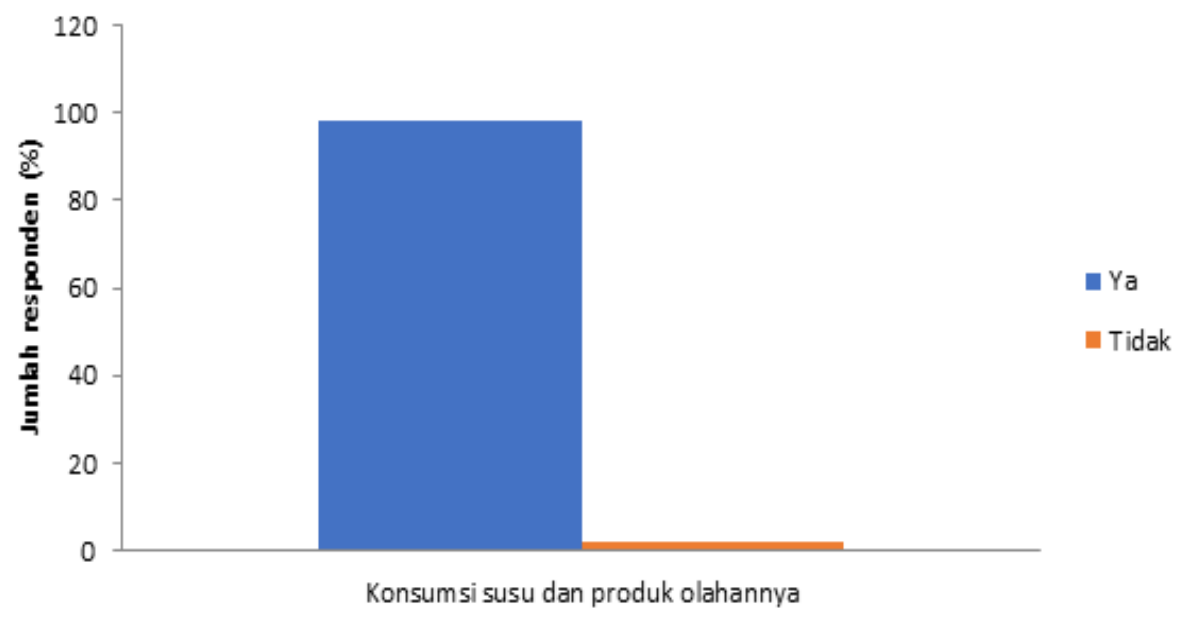

Gambar 1. Tingkat konsumsi susu dan produk olahannya 
Tabel 3. Analisis hubungan pengetahuan dengan perilaku konsumen

\begin{tabular}{|c|c|c|c|}
\hline $\begin{array}{c}\text { Korelasi } \\
\text { Spearman }\end{array}$ & & Pengetahuan & $\begin{array}{l}\text { Keputusan } \\
\text { Konsumsi }\end{array}$ \\
\hline \multirow[t]{3}{*}{ Pengetahuan } & $\begin{array}{c}\text { Koefisien } \\
\text { korelasi }\end{array}$ & 1000 & $0.483^{\prime \prime}$ \\
\hline & Sig (2-tailed) & & 0.00 \\
\hline & Jumlah (N) & 108 & 108 \\
\hline \multirow[t]{3}{*}{$\begin{array}{l}\text { Keputusan } \\
\text { Mengonsumsi }\end{array}$} & $\begin{array}{c}\text { Koefisien } \\
\text { korelasi }\end{array}$ & $0.483 ”$ & 1000 \\
\hline & Sig (2-tailed) & 0.00 & \\
\hline & Jumlah (N) & 108 & 108 \\
\hline
\end{tabular}

Sumber: Data primer yang diolah (2021)

mempengaruhi keputusan mengonsumsi 32.09\% tidak setuju, $17.28 \%$ setuju dan $0.92 \%$ sangat tidak setuju (Tabel 4).

Kedua variabel tersebut menurut responden dapat mempengaruhi keputusan mereka mengonsumsi dilihat pada Tabel 4 didapat $58.56 \%$ setuju, $21.76 \%$ sangat setuju, $18.05 \%$ tidak setuju, dan $1.06 \%$ sangat tidak setuju. Hasil menunjukkan responden paling banyak setuju bahwa faktor pengetahuan dan kondisi situasional konsumen akan suatu produk dapat mempengaruhi keputusan mengonsumsi. Responden rata-rata sudah memiliki pengetahuan yang tinggi terkait produk susu, sehingga hal ini mempengaruhi terkait keputusan konsumen dalam mengonsumsi produk tersebut. Menurut Swastha dan Handoko (2000) pengetahuan yaitu unsur-unsur yang mengisi akal dan alam jiwa seorang manusia yang sadar, secara nyata terkandung dalam otaknya, sehingga persepsi konsumen terhadap suatu produk juga dipengaruhi dari berbagai pengetahuan dan informasi yang didapat sehingga mempengaruhi keputusan konsumen dalam membeli dan mengonsumsi produk. selain itu, kondisi situasional juga pada gambar tersebut ikut mempengaruhi tingkat konsumsi responden. Produk yang ditawarkan terhadap konsumen akan dipilih berdasarkan pengaruh karakteristik dari produk maupun jasa. Situasional merupakan salah satu aspek yang mempengaruhi konsumsi konsumen.

Tabel 4. Distribusi responden berdasarkan pernyataan sikap terhadap susu dan produk olahannya

\begin{tabular}{lcccc}
\hline \multirow{2}{*}{ Variabel } & \multicolumn{4}{c}{ Jumlah persentase (\%) } \\
\cline { 2 - 5 } & $\begin{array}{c}\text { Sangat } \\
\text { setuju }\end{array}$ & Setuju & $\begin{array}{c}\text { Tidak } \\
\text { setuju }\end{array}$ & $\begin{array}{c}\text { Sangat tidak } \\
\text { setuju }\end{array}$ \\
\hline Pengetahuan & 39.62 & 56.29 & 3.51 & 0.56 \\
Situasional & 17.28 & 49.69 & 32.09 & 0.92 \\
$\begin{array}{l}\text { Keputusan } \\
\text { Mengonsumsi }\end{array}$ & 21.76 & 58.56 & 18.05 & 1.62 \\
\hline
\end{tabular}

\section{Hubungan Pengetahuan dan Situasional terhadap Perilaku Konsumen}

Pengaruh pengetahuan terhadap perilaku konsumen hasil perhitungan antara variabel bebas berupa pengetahuan terhadap variabel terikat berupa keputusan mengonsumsi terhadap produk susu dan produk olahannya, terdapat hubungan antara pengetahuan dan keputusan mengonsumsi didapatkan data korelasi dengan hubungan sedang. Hasil ditunjukkan dari koefisien korelasi variabel pengetahuan dengan keputusan konsumen sebesar 0.483 yang juga memiliki arah positif (Tabel 5). Hal ini menunjukkan terdapat hubungan yang kuat antara pengetahuan dengan keputusan mengonsumsi dan memiliki nilai positif.

Menurut pernyataan Engel (1994) dimana perilaku konsumen dapat dipengaruhi dari faktor internal maupun eksternal. Faktor pengetahuan ini merupakan salah satu yang ikut mempengaruhi perilaku konsumen yang berasal dari faktor internal. Pengetahuan konsumen merupakan informasi yang dimiliki oleh konsumen mengenai berbagai macam produk dan jasa (Hurriyati 2010). Pengetahuan dapat memudahkan konsumen dalam menentukan pilihan terhadap pembelian produk, begitu pula pada produk olahan hasil ternak seperti susu. Konsumen melihat suatu produk dari berbagai karakteristik, yaitu karakteristik fisik, manfaat produk serta nilai kepuasan setelah konsumen pernah membeli produk tersebut (Peter dan Olson 1999). Karakteristik fisik seperti kemasan, merek maupun hal yang mencakup penjelasan deskripsi produk dapat dilihat langsung oleh konsumen. Informasi yang terdapat pada produk ini dapat mempengaruhi daya beli konsumen. Begitu pula manfaat yang dapat dirasakan konsumen ketika mengonsumsi produk ikut mempengaruhi tingkat konsumsi terhadap konsumen. Susu telah banyak diketahui oleh konsumen akan manfaat dan kandungan gizinya yang tinggi. Produk susu serta olahannya juga telah menjadi kebiasaan konsumsi oleh konsumen (Gambar 1). Pemahaman konsumen akan kandungan gizi yang tinggi pada susu menyebabkan angka konsumsi susu terus meningkat setiap tahunnya.

Tabel 5. Analisis hubungan situasional dengan perilaku konsumen

\begin{tabular}{lccc}
\hline $\begin{array}{c}\text { Korelasi } \\
\text { Spearman }\end{array}$ & Pengetahuan & $\begin{array}{c}\text { Keputusan } \\
\text { Konsumsi }\end{array}$ \\
\hline Situasional & $\begin{array}{c}\text { Koefisien } \\
\text { korelasi } \\
\end{array}$ & 1000 & 0.395 \\
& Sig (2-tailed) & & 0.00 \\
& Jumlah (N) & 108 & 108 \\
Keputusan & Koefisien & 0.395 & 1000 \\
Mengonsumsi & korelasi & & \\
& Sig (2-tailed) & 0.00 & \\
& Jumlah (N) & 108 & 108 \\
\hline
\end{tabular}

Sumber: Data primer yang diolah (2021)

Pengaruh situasional terhadap perilaku konsumen hasil perhitungan antara variabel bebas berupa situasional terhadap variabel terikat berupa keputusan mengonsumsi terhadap produk susu dan produk olahannya, terdapat hubungan antara kondisi situasional dan keputusan mengonsumsi didapatkan data korelasi dengan hubungan sedang hal ini ditunjukkan dari koefisien korelasi variabel situasional dengan keputusan konsumen sebesar 0.395 yang juga memiliki arah positif. Pengaruh situasi muncul dari faktor berdasarkan waktu dan lokasi yang berhubungan dengan karakteristik konsumen dan objek. Karakteristik pada situasi konsumen antara lain lingkungan fisik, waktu, sosial dan keadaan sekitar. Terdapat beberapa jenis situasi 
konsumen yaitu seperti situasi pemakaian. Pembelian dan konsumsi.

Lokasi yang mudah terjangkau dan mudah ditemui oleh konsumen dapat memudahkan pembelian suatu produk oleh konsumen. Saat ini banyaknya berbagai lokasi yang menjual susu di beberapa toko dan swalayan menjadi penyebab meningkatkan konsumsi produk tersebut. Kota Bogor yang termasuk wilayah perkotaan dan dekat dengan ibu Kota Jakarta, tentunya terdapat berbagai lokasi penjualan susu yang mudah ditemui konsumen. Lingkungan fisik yang menunjukkan beberapa tempat penjualan susu yang berada disekitar konsumen sehari-harinya mampu mempengaruhi konsumen dalam membeli produk tersebut (Belk 1975).

Kondisi lingkungan sosial yang terjadi dimasyarakat juga mampu menjadi aspek yang mempengaruhi perilaku konsumen (Belk 1975). Konsumen dapat mengetahui akan respon bagusnya suatu produk seperti kualitas dan segi keamanan dari produk susu dan olahannya dari orang di lingkungan sekitarnya seperti teman, tetangga maupun saudara, yang dapat memberikan stimulasi bagi konsumen untuk ikut membeli produk tersebut. Perspektif waktu merupakan situasi yang dikategorikan dengan waktu dan situasi tertentu. Seperti adanya waktu dimana terjadi diskon besar-besaran pada produk pada tanggal khusus tertentu. Selain itu,trend yang berubah-ubah dimasyarakat juga dapat mempengaruhi dimana saat ini angka konsumsi pangan yang berkhasiat tinggi untuk meningkatkan imunitas tubuh semakin tinggi sehingga konsumsi susu dan produk olahannya yang termasuk kedalam pangan berkhasiat juga ikut meningkat.

\section{KESIMPULAN}

Konsumen susu dan produk olahannya yang berasal dari wilayah kota Bogor dengan rentang usia 20 hingga 30 tahun rata-rata dimasa pandemi COVID-19 memiliki tingkat konsumsi susu yang sangat tinggi. Hal ini dapat dilihat dari persentase 96\% konsumen mengonsumsi susu dan produk olahannya dan hanya 4\% saja yang belum mengonsumsi. Hubungan antara variabel pengetahuan dan situasional terhadap perilaku mengonsumsi susu dan produk olahannya pada konsumen yaitu cukup kuat. Semakin tinggi tingkat informasi yang dimiliki konsumen makan akan semakin meningkatkan konsumsi susu dan produk olahannya. Kondisi situasional berupa lingkungan sekitar seperti keluarga menjadi salah satu faktor dalam keputusan konsumen hal ini karena adanya faktor dari eksternal yang mempengaruhi konsumen, selain itu lokasi penjualan produk juga ikut mempengaruhi tingkat konsumsi, dimana lokasi yang dekat akan mudah didatangi oleh konsumen.

\section{DAFTAR PUSTAKA}

Belk, R. 1975. An Exploratory Assessment of Situasional Effect in Buyer Behavior. Journal of Marketing Research. 14:156-163. https://doi.org/10.1177\% 2F002224377401100206.

Belk, R. 1975. Situational Variabels and Consumer Behavior. Journal of Consumer Research. 2:157-164. https://www.jstor.org/stable/2489050.

BPS (Badan Pusat Statistik). 2016. Statistik Daerah Kota Bogor. Jakarta: Badan Pusat Statistik Kota Bogor.

BSN (Badan Standarisasi Nasional Indonesia). 2011.
Susu segar-bagian1:sapi. SNI 3141.1:2011. Jakarta: Badan Standarisasi Nasional Indonesia.

Dharmesta, B. S., \& Irawan. 1999. Manajemen Pemasaran Modern. Ed ke-2. Yogyakarta : Liberty.

Durianto, D., Sugiarto, \& T. Sitinjak. 2004. Strategi Menaklukkan Pasar Melalui Riset Ekuitas dan Perilaku Merek. Jakarta: Gramedia Pustaka Utama.

Engel, \& F. James, dkk. 1994. Perilaku Konsumen. Edisi ke-6. Jakarta Barat: Binarupa Aksara.

Fazrina, Rahma, Marsaulina, Irnawati, Naria, \& Evi. 2013. Hubungan Karakteristik dan Pengetahuan Tentang Lingkungan Sehat Dengan Keputusan Konsumen Dalam Membeli Sayuran Organik di Carrefour Plaza Medan Fair. Jurnal Program Sarjana Fakultas Kesehatan Masyarakat Universitas Sumatera Utara. Medan.

Ghozali, \& Imam. 2011. Aplikasi Analisis Multivariate Dengan Program IBM SPSS19. Semarang: Badan Penerbit Universitas Diponegoro.

Hartono, A. 2006. Terapi Gizi dan Diet Rumah Sakit. Ed ke-2. Jakarta: Buku Kedokteran EGC:140-147.

Hiam, A, \& C. D. Schewe. 1994. The Portable MBA Pemasaran. Jakarta: Binarupa Aksara.

Hurriyati, \& Ratih. 2010. Bauran Pemasaran dan Loyalitas Konsumen. Bandung: ALFABETHA.

Istiqlal, A. H. 2013. Atribut produk dalam keputusan pembelian konsumen. Jurnal Ekonomi dan Manajemen. 1(1):20-30. https://doi.org/10.30596/jimb.v19i1.1743.

Kotler, K. 2009. Manajemen Pemasaran 1.Edisi ketiga belas. Jakarta: Erlangga.

Peter, J., Paul, C. Jerry, \& Olson. 2010. Consumer Behavior \& Marketing Strategy. Ed ke- 9. New York: Mcgraw Hill.

Rakhmat, J. 2001. Metode Penelitian Komunikasi. Bandung: PT. Remaja Rosdakarya.

Silalahi, U. 2012. Metode Penelitian Sosial. Bandung: PT. Refika Aditama.

Sugiyono. 2005. Memahami Penelitian Kualitatif. Bandung: CVAlfabeta.

Sugiyono. 2013. Metode Penelitian Kuantitatif, Kualitatif dan R\&D. Bandung: Alfabeta CV.

Sukirno, \& Sadono. 2005. Pengantar Teori Makro Ekonomi. Jakarta: PT. Raja Grafindo Persada.

Sukur, M. H., B. Kurniadi, \& F. N. Ray. 2020. Penanganan Pelayanan Kesehatan di Masa Pandemi Covid-19 dalam Perspektif Hukum Kesehatan. Journal Inicio Legis.1(1).

Swastha, B., \& T. H. Handoko. 2000. Manajemen Pemasaran (Analisa Perilaku Konsumen). Yogyakarta: BPFE UGM.

Taufik, E. 2021. Respon Atas Terjadinya Panic Buying Susu Steril "Merk Tertentu" dalam Kaitannya dengan Pencegahan Infeksi Covid-19. [ISPI] Perkumpulan insinyur dan sarjanan peternakan Indonesia. [Diunduh pada tanggal 4 oktober 2021] https://pb-ispi.org/ respon-atas-terjadinya-panic-buying-susu-steril-merktertentu-dalam-kaitannya-dengan-pencegahan-infeksicovid-19/. 